\title{
A STUDY OF THE EFFECTS OF ELECTRONIC TEXTBOOK-AIDED REMEDIAL TEACHING ON STUDENTS' LEARNING OUTCOMES AT THE OPTICS UNIT
}

\author{
Chen-Feng Wu, Pin-Chang Chen and Shu-Fen Tzeng \\ Department of Information Management, Yu Da University of Science and Technology, \\ Miaoli, Taiwan
}

\begin{abstract}
Adopting the experimental research approach and test results of students' optics unit learning outcomes as the research tool, this study carried out experimental remedial teaching on 92 research samples who are grade eight students at a junior high school in Miaoli County to investigate the effects of electric textbooks on the optics unit learning outcomes of students with low academic achievement. The results suggest that remedial teaching incorporating electronic textbooks is better than traditional remedial teaching according to the learning outcomes of the grade eight students of low academic achievement in this study.
\end{abstract}

\section{KEYWORDS}

Electronic Textbook, Remedial Teaching, Learning Outcome, Experimental Research.

\section{INTRODUCTION}

Students' academic achievement forms a normalized distribution. Li (2001) divided students' academic achievement into four levels: high achievement, medium-high achievement, mediumlow achievement, and low achievement [1]. To ensure each elementary school and junior high school student' basic academic competence, the National Twelve-year Public Education mentioned about providing remedial teaching to students of medium-low academic achievement and low academic achievement.

In 1997, the Ministry of Education (MOE) commenced to promote information and computer education and built an equal and good quality digital education environment and multifunctional e-specialized classrooms for elementary school and secondary schools. In 2008, the Ministry of Education launched the "Taiwan e-Learning and Digital Archives Program" (TELDAP), incorporated the industrial, academic, and research experts as well as elementary school and secondary school teachers to develop and integrate applicable, practical, and creative digital learning resources into teaching in an attempt to achieve the goal of using digital learning to improve teaching. The learning outcomes facilitated by electronic textbooks were the most solid outcomes [2]. If teachers could utilize the school's existing IT equipment and incorporate electronic textbooks to provide remedial teaching to students who fall behind with their schoolwork or have low academic achievement, it may be possible to notice improvements in students' attitudes toward learning, motivation to learn, and learning outcomes. Hence, it is imperative to commence studies on this possibility.

Considering that there are always students with low motivation to learn and poor learning outcomes when learning science and life technology, this research sets out to choose grade eight 
students of low academic achievement as the research participants in this study to explore the effects of electronic textbooks and traditional remedial teaching on students' learning outcomes.

\section{LITERATURE REVIEW}

Remedial teaching, which originated from the policies of "Collaboration Plan - After-School Assistance" and "Education Priority Areas Project - Learning Guidance", aims to reinforce assistance to students of low academic achievement and from disadvantaged families. Chang (2001) proposed that remedial teaching is a type of diagnostic teaching (also known as clinical teaching) for students of low academic achievement [3]. The course of remedial teaching encompasses the cycle of "assessment - teaching - re-assessment". The Ministry of Education delegated the National University of Tainan to complete a system to evaluate the learning outcomes of junior high school students at all grades in terms of students' knowledge of the basic content in all academic subjects such as Chinese, English, and Mathematics. This evaluation system could also be used to determine students who need learning guidance and assistance. Students' evaluation results were normalized by using the evaluation system and students who were at the bottom $35 \%$ of the normalization had to receive remedial teaching [4]. Given that a standard evaluation system for students' performance in science was under development, the researcher selected students whose performance at an exam was at the bottom $35 \%$ of each class as students to receive remedial teaching, which was approximately $1 / 3$ of the total students in one class.

In the course of teaching delivery, textbooks are what teachers' teaching activities are based on as well as important resources for students' acknowledge acquisition [5]. Paper-based textbooks are mostly texts and graphics. In line with information technologies' rapid development, the Ministry of Education began to promote the integration of information technologies into teaching delivery and subsidized the information technology software and hardware equipment at schools at all levels. In addition, since civilian publishers were allowed to design elementary school and junior high school textbooks for the Ministry of Education's review and final decisions, the formats of textbooks are not restricted to traditional paper-based course materials. Instead, publishers also provide teachers with electronic textbooks for teaching purposes [6].

Electronic textbooks are education media for teachers or students and are designed and burned to a CD disk through computer programing [7]. Lin and Hsu pointed out that computer-aided teaching is a gradually adopted remedial teaching mode in recent years [8]. By using texts, graphics, videos, animations, flash interactive course materials, resources and links on the Internet, teachers could conduct immediate assessments of students' learning outcomes and proceed with remedial teaching. By using electronic textbooks, students can watch video clips of demonstrated learning and the simulation of the process of experiments, use the interactive learning materials, achieve a better understanding of scientific viewpoints and abstract concepts, and review what they have learned with the help of IT equipment [9]. In light of this, incorporating electronic textbooks alongside computer and information technologies into remedial teaching to teach the optics unit to students of low academic achievement, this study proposed to look into whether incorporating electronic textbooks into remedial teaching could improve the learning outcomes of students of low academic achievement.

\section{RESEARCH METHOD}

\subsection{Research Design}

As using random sampling to select research participants for this study was impossible, the experimental research method, which is commonly used in studies of natural sciences, was 
utilized in this study [10]. The experiment commenced after the independent variable was changed and other variables were controlled. Relevant data for the experiment were collected and special attention was paid to the independent variable's effects on the dependent variables. Further, results demonstrated by data of the experiment were analyzed to come up with research conclusions and suggestions.

Attempting to investigate different learning outcomes of students of low academic achievement on the optics unit after receiving electronic book-aided remedial teaching and traditional remedial teaching respectively, the researcher of this study chose the bottom $35 \%$ students in each grade 8 class as the research participants based on students' exam performance on the optics unit in the grade 8 curriculum. Furthermore, this research adopted a non-random sampling method to divide the research participants into a control group and an experimental group.

Students in the control group received traditional remedial education whereas students in the experimental group received remedial teaching aided by electronic textbooks. Before and after the remedial teaching on the optics unit, students in both the control group and the experimental group were required to sit an exam designed for the optics unit to find out students' knowledge of this unit.

\subsection{Research Tools}

Research tools used in this study include electronic textbooks and the students' optics unit learning outcomes test. Further explanations of the two research tools are as follows:

\subsubsection{Electronic Textbook}

Grade eight science and technology e-textbooks by Kang Hsuan Educational Publishing Group (first semester).

\subsubsection{Optics Unit Learning Outcomes Test}

The optics unit learning outcomes test was designed in accordance with the course content, indicators of students' competence at different stages, and teaching objectives of the optics unit in the field of science and life technology set out in the General Guidelines of Grade 1-9 Curriculum of Elementary and Junior High School. The test questions encompass 30 questions in total, which were two knowledge questions, nine comprehension questions, nine analytical questions, six utilization questions, and four integrated questions. Prior to the official test was designed, a pretest was run on two grade nine classes, which consist of a total of 74 students who did not take part in this experiment, at a junior high school in Miaoli County. Subsequent analyses were run on the test's question difficulty and question discrimination alongside validity tests and reliability tests to provide a guideline for preparing the official test. This study set the top 33\% of students (24 students) at the test as students in the group of high grades whereas the bottom $33 \%$ of students (24 students) at the test as students in the group of low grades. Furthermore, this study counted how many correct answer each test question received from students in both groups and calculated the correctness rate of answers by students in both groups to derive each question's question difficulty and question discrimination. A question difficulty level between 0.4-0.8 and a question discrimination level higher than 0.3 were used as the guideline for the selection of questions. According to the analysis of the pretest's question difficulty and discrimination, questions 1,3,6,19,24 did not meet the set criteria and therefore were deleted to leave a total of 25 questions on the official test. Further, the official test's internal consistency was measured with Cronbach's alpha coefficient. The Cronbach's alpha value created by L. J. Cronbach (1951) is commonly used to test the reliability of a Likert attitude scale. The reliability of the optics unit 
learning outcomes test has a Cronbach's alpha value of 0.924 , indicating a very satisfactory reliability. In terms of the validity analysis, content analysis (also known as expert validity) was adopted to analyze the validity of the test questions. Aside from discussing with the advising professor about the validity of the test questions, four experts in the field of science and life technology were invited to review, modify, and finalize the test questions.

\subsection{Data Collection and Analysis}

Beginning with collecting students' answers to the optics unit learning outcomes test before and after the remedial teaching (which are hereafter referred to the pretest and posttest), this study further organized these collected data and keyed in students' answers into the 14.0 Chinese version of SPSS Statistics, a software package used for statistical analysis, and conducted the following statistical analysis:

\subsubsection{Descriptive Statistics}

Displaying data includes mean, standard deviation, and mean deviation.

\subsection{2. $t$ Test}

1. Examining students' answers to pretest of the "optics unit learning outcomes" and using the independent sample test to validate that the basic competency of students in the experimental group and the control group are homogeneous.

2. Using the pared-samples t-test to analyze if the learning outcomes were significantly different for the experimental group students who received electronic textbook-aided remedial teaching and the control group students who received traditional remedial teaching before and after the remedial teaching.

3. Using the independent sample test to validate whether the experimental group students and the control group students showed significant difference in learning outcomes after the remedial teaching.

\section{RESEARCH RESULTS AND DISCUSSION}

Proposing to investigate the effect of electronic textbook-aided remedial teaching, this study adopted the experimental research method and chose a total of 92 grade eight students from three classes at a junior high school in Miaoli County in the 2014 Academic Year as the research subjects. Next, this study used the optics unit learning outcomes test to select the bottom $35 \%$ of students in each class as the research participants, which resulted in a total of 30 students as the research participants. Using a non-random method of grouping, 15 students from the 30 students were allocated to the experimental group to receive electronic textbook-aided remedial teaching whereas the other 15 students were allocated to the control group to receive traditional remedial teaching. After both groups of students received the remedial teaching, both groups of students took the optics unit learning outcomes test again and the researchers analyzed students 'performance on the test to obtain the research results.

In order to proceed to study the effects of electronic textbook-aided remedial teaching and traditional remedial teaching, students in the experimental group and the control group needed to have the same level of starting competency. In light of this, the 30 students were carefully allocated to the two groups to ensure that the two groups were made up of students whose mean score on the pretest was similar to the pretest mean score of students in another group. The independent sample test was adopted to validate the homogeneous competency of students in the 
control group and the experimental group at the pretest. Further, various tests were adopted to validate whether the experimental group showed significant difference on the pretest and posttest scores, whether the control group showed significant difference on the pretest and posttest scores, and whether the control group and the experimental group showed significant difference on the posttest scores.

The verification of the homogeneity of students in the experimental group and students in the control group is shown in Table 1 and Table 2. According to the statistics of students' test scores and the independent sample test analysis, students in the experimental groups and students in the control groups had no significant difference in their scores at the pretest of the optics unit learning outcomes. As such, the assumption that the basic competency of students in both groups belonged to a homogeneous group was validated.

Table 1. Statistics of the experimental group students and the control group students' scores at the pretest of the optics unit learning outcomes

\begin{tabular}{|c|c|c|c|c|c|c|}
\hline Group & Quantity & Mean & $\begin{array}{l}\text { Standard } \\
\text { deviation }\end{array}$ & $\begin{array}{c}\text { Standard error of } \\
\text { the mean }\end{array}$ & $\begin{array}{l}\text { The mean } \\
\text { difference } \\
\text { (the experimental } \\
\text { group - the } \\
\text { control group) }\end{array}$ & $\begin{array}{c}\text { The percentage } \\
\text { of the mean } \\
\text { difference }\end{array}$ \\
\hline $\begin{array}{l}\text { The } \\
\text { experime } \\
\text { ntal } \\
\text { group }\end{array}$ & 15 & 10.600 & 1.639 & 0.423 & \multirow[t]{2}{*}{0.133} & \multirow[t]{2}{*}{$1.27 \%$} \\
\hline $\begin{array}{l}\text { The } \\
\text { control } \\
\text { group }\end{array}$ & 15 & 10.467 & 1.457 & 0.376 & & \\
\hline
\end{tabular}

Table 2. Statistics of the t test of the experimental group students and the control group students' scores on the pretest of the optics unit learning outcomes

\begin{tabular}{|c|c|c|c|c|c|c|c|c|}
\hline & \multicolumn{3}{|c|}{$\begin{array}{c}\text { Levene's Test for } \\
\text { Equality of } \\
\text { Variances } \\
\end{array}$} & \multicolumn{5}{|c|}{ t-test for equal means } \\
\hline & \multirow{2}{*}{$\begin{array}{c}\mathrm{F} \\
\text { test }\end{array}$} & \multirow{2}{*}{ Significance } & \multirow[t]{2}{*}{$\mathrm{T}$} & \multirow{2}{*}{$\begin{array}{l}\text { Degree } \\
\text { of } \\
\text { freedom }\end{array}$} & \multirow{2}{*}{$\begin{array}{c}\text { Significance } \\
\text { (two -tailed } \\
\text { ) }\end{array}$} & \multirow{2}{*}{$\begin{array}{c}\text { Mean } \\
\text { deviation }\end{array}$} & \multirow{2}{*}{$\begin{array}{l}\text { Standard } \\
\text { error of } \\
\text { difference } \\
\text { between } \\
\text { two } \\
\text { Means }\end{array}$} & $\begin{array}{c}95 \% \\
\text { confidence } \\
\text { intervals for } \\
\text { differences }\end{array}$ \\
\hline & & & & & & & & $\begin{array}{l}\text { The The } \\
\text { lower upper } \\
\text { bound bound }\end{array}$ \\
\hline $\begin{array}{l}\text { Assuming } \\
\text { the equality } \\
\text { of variances }\end{array}$ & 1.003 & 0.325 & 0.235 & 28.000 & 0.816 & 0.133 & 0.566 & $-1.027 \quad 1.293$ \\
\hline $\begin{array}{l}\text { Not } \\
\text { assuming } \\
\text { the equality } \\
\text { of variances }\end{array}$ & & & 0.235 & 27.623 & 0.816 & 0.133 & 0.566 & $\begin{array}{ll}-1.027 & 1.294\end{array}$ \\
\hline
\end{tabular}

The statistics of the experimental group students' scores at the pretest and the posttest of the optics unit learning outcomes are presented in Table 3 and results of the $t$ test are presented in 
Table 4. The results revealed that there was significant difference between the experimental group students' scores at the pretest and the posttest of the optics unit learning outcomes, and the score at the posttest (mean score $=19.800$ ) is higher than the score at the pretest (mean score $=10.600$ ).

Table 3. Statistics of the experimental group students' scores at the pretest and the posttest of the optics unit learning outcomes

\begin{tabular}{lcrrrrr}
\hline Group & Quantity & Mean & $\begin{array}{c}\text { Standard } \\
\text { deviation }\end{array}$ & $\begin{array}{c}\text { Standard error of } \\
\text { the mean }\end{array}$ & $\begin{array}{c}\text { The mean } \\
\text { difference } \\
\text { (posttest - } \\
\text { pretest ) }\end{array}$ & $\begin{array}{c}\text { The percentage } \\
\text { of the mean } \\
\text { difference }\end{array}$ \\
\hline Pretest & 15 & 10.600 & 1.639 & 0.423 & 9.200 & $86.79 \%$ \\
\hline Posttest & 15 & 19.800 & 4.109 & 1.061 & & \\
\hline
\end{tabular}

Table 4. Statistics of the paired-samples t-test of the experimental group students' scores at the pretest and the posttest of the optics unit learning outcomes

\begin{tabular}{lccr}
\hline & T value & Degree of freedom & Significance(two-tailed) \\
\hline $\begin{array}{l}\text { The pretest and posttest of the } \\
\text { experimental group students }\end{array}$ & -12.051 & 14 & 0.000 \\
\hline
\end{tabular}

The statistics of the control group students' scores at the pretest and the posttest of the optics unit learning outcomes are presented in Table 5 and results of the $t$ test are presented in Table 6 . The results revealed that there was significant difference between the control group students' scores at the pretest and the posttest of the optics unit learning outcomes, and the score at the posttest (mean score $=12.333$ ) is higher than the score at the pretest (mean score $=10.467$ ).

Table 5. Statistics of the control group students' scores at the pretest and the posttest of the optics unit learning outcomes

\begin{tabular}{lcrrrrc}
\hline Group & Quantity & Mean & $\begin{array}{c}\text { Standard } \\
\text { deviation }\end{array}$ & $\begin{array}{c}\text { Standard error of } \\
\text { the mean }\end{array}$ & $\begin{array}{c}\text { The mean } \\
\text { difference } \\
\text { (posttest - } \\
\text { pretest) }\end{array}$ & $\begin{array}{c}\text { The percentage of } \\
\text { the mean } \\
\text { difference }\end{array}$ \\
\hline Pretest & 15 & 10.467 & 1.457 & 0.376 & 1.866 & $17.83 \%$ \\
\hline Posttest & 15 & 12.333 & 1.175 & 0.303 & & \\
\hline
\end{tabular}

Table 6. Statistics of the t test of the control group students' scores at the pretest and the posttest of the optics unit learning outcomes

\begin{tabular}{lrcr}
\hline & T value & Degree of freedom & Significance(two-tailed) \\
\hline $\begin{array}{l}\text { The pretest and posttest of } \\
\text { the control group students }\end{array}$ & -4.404 & 14 & 0.001 \\
\hline
\end{tabular}

The statistics of the experimental group students and the control group students' scores at the posttest of the optics unit learning outcomes are presented in Table 7 and results of the test are presented in Table 8 . The results revealed both the experimental group students and the control group students showed significant difference at the posttest of the optics unit learning outcomes, and the experimental group's score at the posttest (mean score $=19.800$ ) is higher than the control group's score at the posttest (mean score $=12.333$ ). 
Table 7. Statistics of the control group students and the experimental group students' scores on the posttest of the optics unit learning outcomes

\begin{tabular}{lccccc}
\hline Group Quantity & Mean $\begin{array}{c}\text { Standard } \\
\text { deviation }\end{array}$ & $\begin{array}{c}\text { Standard error of } \\
\text { the mean }\end{array}$ & $\begin{array}{c}\text { The mean } \\
\text { difference } \\
\text { (the experimental } \\
\text { group - the control } \\
\text { group) }\end{array}$ & $\begin{array}{c}\text { The percentage } \\
\text { of the mean } \\
\text { difference }\end{array}$ \\
$\begin{array}{l}\text { The } \\
\text { control } \\
\text { group }\end{array}$ & 15 & 12.333 & 1.175 & 0.303 & \\
$\begin{array}{c}\text { The } \\
\text { experime } \\
\text { ntal } \\
\text { group }\end{array}$ & 15 & 19.800 & 4.109 & 1.061 & \\
\hline
\end{tabular}

Table 8. Statistics of the t test of the experimental group students and the control group students' scores at the posttest of the optics unit learning outcomes

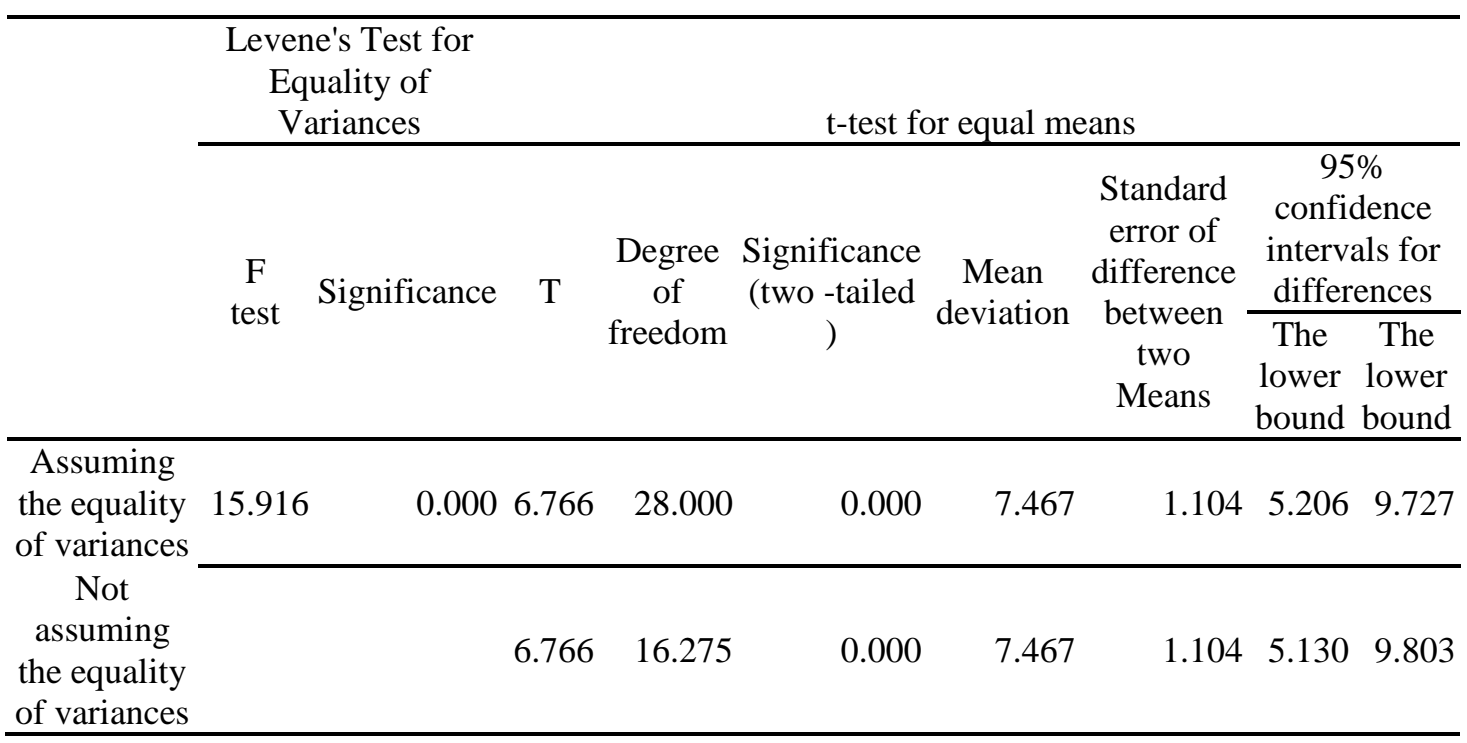

The above data showed that the experimental group students and the control group students had similar mean scores at the pretest and proved having no significant difference after the independent sample test. It indicated that prior to the remedial teaching, the experimental group students and the control group students' basic competency in the optics unit appeared homogeneous. Therefore, it can be assumed that the basic competency of students in both groups were the same before the remedial teaching. After the experimental group students received electronic textbook-aided remedial teaching and the control group students received traditional remedial teaching, both groups of students sat the optics unit learning outcomes test, and the mean test scores of both groups were higher than the mean tests score of both groups prior to the remedial teaching. In addition, given that both groups' test scores before and after the remedial teaching showed significant difference, it can be inferred that remedial teaching could enhance the learning outcomes of students of low academic achievement. Furthermore, the experimental 
group students' mean score on the posttest was higher than the control group students' mean score on the posttest, and two groups of students' mean scores on the posttest had reached a significant difference, denoting that the effect of electronic textbook-aided remedial teaching is better than the effect of traditional remedial teaching.

\section{CONCLUSION}

The conclusion of this study is that using electronic textbooks to provide remedial teaching on the optics unit to grade eight students of low academic achievement could enhance students' learning outcomes. In addition, compared with traditional remedial teaching, using electronic textbookaided remedial teaching could result in students' better exam performance.

After using electronic textbooks to provide remedial teaching to students of low academic achievement, students show significant difference in the use of electronic textbooks and learning outcomes at the optics unit. At the period of the experiment, it was also discovered further studies could delve into relevant issues such as teaching strategies and collaborative group learning, research methodology and qualitative data, as well as suitable students and applicable research units of electronic textbooks to reach conclusions close to perfection and provide a reference for researchers in the future.

\section{REFERENCES}

[1] Li, Y.Y., (2001) Learning Guidance - Applications of the Psychology of Learning, Taipei: Psychological Publishing.

[2] Lin, Y.C., (2008) “The Digital Learning Program in Formal Education”, 2008 White Paper on Digital Learning, pp. 39-42.

[3] Chang, H.J., (2001) "Curriculum and Teaching Designs for the Implementation of Remedial Education", Journal of Education, Vol. 17, pp. 85-106.

[4] Ministry of Education, (2013) "The National Twelve-year Basic Education Plan", retrieved from: http://12basic.edu.tw/detail.php?LevelNo=8

[5] Huang, W.T. \& Chen, L.H., (2012) "The Future Trends of Textbook Design and Development - the Social Studies Field as an Example", Reading is Beneficial: the Review and Prospect of Textbooks, pp. 619-654.

[6] Chesser, W. D., (2011) “The E-textbook Revolution”, Library Technology Reports, Vol. 47, No. 8, pp. 28-40.

[7] Vassiliou, M. \& Rowley, J., (2008) "Progressing the Definition of E-book", Library Hi-Tech, Vol. 26, No. 3, pp. 360-364.

[8] Lin, C.H. \& Hsu, W.C., (2007) "The Effects of Online Learning on Remedial Teaching of Junior High School Mathematics - the Linear Equation with One Unknown Unit in the Seventh Grade Curriculum as an Example", Journal of Educational Resources and Research, Vol. 78, pp. 227-248.

[9] Miles, M. L, \& Cooper, B.S., (2009) "Reimagining the Textbook", Education Weekly, Vol. 29, No. 11 , pp. 24-25.

[10] Wang, W.K. \& Wang, C.H., (2008) Educational Research Methodology (revised 12th edition), Taipei: Wu Nan Book. 